\title{
Presidentas Rise: Consequences for Women in Cabinets?
}

Catherine Reyes-Housholder

\begin{abstract}
Since 1999, women have democratically won the presidency eight times in Latin America and have named hundreds of ministers. This study argues that under certain conditions, presidentas are more likely than male presidents to improve women's cabinet representation. Two mechanisms, presidenta mandates and gendered networks, appear to drive the relationship. Furthermore, because the pool of ministerial candidates is shallower for women than for men, presidentas are most likely to advance women's representation in cabinets at the beginning of their term and for "feminine" ministries. A case study of Michelle Bachelet's 2006 ministerial appointments reveals initial evidence for the argument. Empirical implications are then tested with an original dataset of 1,908 ministers of all democratically elected Latin American presidents since 1999. Model results are consistent with the theory that presidentas are most likely to "make a difference" when they are least constrained by the supply of female ministerial candidates.
\end{abstract}

$\mathrm{M}$ inisterial positions offer Latin American politicians national-level visibility and power. Appointees draft, promote, and execute legislation, and cabinets are recruiting grounds for future presidential candidates. Women still constitute only about 20 percent of the region's ministerial posts. Given the power of these offices, this underrepresentation severely limits the potential for political equality between men and women.

Yet one understudied and possibly consequential trend in Latin America is the rise of presidentas. Women have democratically captured the presidency eight times since 1999 - more times than in any other region in the world. ${ }^{1}$ Presidents are constitutionally unconstrained in appointing ministers (Shugart and Carey 1992; Payne 2007). The main argument of this article is that presidentas - particularly when they are least constrained-are more likely than male presidents to appoint ministras. Thus, in addition to breaking the highest glass ceiling, women presidents in Latin America often do improve women's presence in executive cabinets.

Two mechanisms converge on the prediction that, ceteris paribus, presidentas will appoint more ministras than male presidents. First, presidentas are more likely than male presidents to interpret part of their own mandates as popular demands for greater female presence in the executive branch. Second, because presidentas'

Catherine Reyes-Housholder is a doctoral candidate in the Department of Government at Cornell University. cgr46@cornell.edu 
political networks will probably contain more elite female politicians than male presidents' networks, presidentas are more likely to perceive female ministerial candidates to be loyal and like-minded.

Given these affinities between presidentas and ministras, this article contends that presidentas are most likely to "make a difference" when they are least constrained, and that one of the most important constraints is the supply of female ministerial candidates. Presidents seek "competent" ministers-meaning those with political capital resources-to govern effectively, and thus political capital resources are an important determinant of ministerial supply. This imperative dramatically reduces the female pool of ministeriables (qualified ministerial candidates). It follows that presidentas are most likely to nominate more ministras than male presidents when the supply of women ministerial candidates is most abundant. Conversely, presidentas behave similarly to their male counterparts when the female supply is low or depleted.

This argument is probed by examining opportunities and constraints in cabinet decisionmaking during Michelle Bachelet's first term in office (2006-10). This case study illustrates how Bachelet's popular mandate and elite networks help explain her gender parity cabinet. The argument is then tested statistically with a dataset of all ministers appointed by democratically elected presidents in 18 Latin American countries from 1999 to 2015. The results show that the relationship between presidentas and ministras is statistically significant at the $\mathrm{p}<0.10$ level. Consistent with this article's argument, the most robust relationships between presidentas and ministras occur when presidentas enjoy the most decisionmaking latitude in terms of the supply of female ministerial candidates.

This research suggests that the presence of women in the executive branch could have important implications for Latin American democracies. Empirical studies in this region and other parts of the world link higher numbers of women in government to reduced corruption, policy outcomes favoring women, and greater satisfaction with democracy (Dollar et al. 2001; Schwindt-Bayer 2010; SchwindtBayer and Mishler 2005; Swamy et al. 2001). Latin America's political systems have historically underperformed in each of these areas. Potential benefits from greater female leadership in powerful offices therefore provide normative motivations for this and future research.

The comparative literature on female ministerial nominations is sizable (Arriola and Johnson 2014; Barnes and O'Brien 2015; Claveria 2014; Escobar-Lemmon and Taylor-Robinson 2005; Krook and O'Brien 2012; O'Brien et al. 2015; Reynolds 1999). However, to my knowledge, no study to date has systematically examined the impact of female presidents (for a partial exception, see Jalalzai 2016). Because no other region has ever elected such a large number of female presidents, the rise of presidentas in Latin America offers a unique and timely opportunity to advance our understanding of the consequences of the executive's sex for the distribution of formal power between women and men. It also contributes to longstanding debates on the merits of descriptive representation by showing how female presidents "make a difference" and the conditions in which they are more likely to be effective (Dovi 2002; Mansbridge 1999; Phillips 1995; Wangnerud 2009). 


\section{Why Would Presidentas APPOINT WOMEN?}

It is a well-documented tendency and a realistic assumption that all presidents (male or female) aim to fulfill their mandates and achieve their policy objectives (Amorim Neto 2006; Martínez-Gallardo 2012). In light of these fundamental goals, at least two mechanisms converge on the prediction that presidentas will appoint more women to their cabinets. While the first mechanism focuses on bottom-up pressures, the second highlights elite-driven factors.

The first argument relates to presidentas' mandates. A democratic vote allowed each of the presidentas in this study to become the first female chief executive of her country. This suggests these women presidents could justifiably interpret part of their own mandates as popular demands for a greater presence of women in the executive branch. Although increasing women's representation in the executive branch may not be the most important aspect of a presidenta's mandate, it remains that male presidents are less likely than presidentas to infer a public call for greater female representation from their mandate.

Anecdotal evidence supports the intuition that presidentas are more likely than their male counterparts to interpret part of their mandates in this way. Most of the presidentas alluded to their own status as women in their inaugural speeches and expressed a desire to improve gender equality (Archivo Chile 2006; La Nación 2010; Fernández de Kirchner 2007; Palácio do Planalto 2011). Panama's president, Mireya Moscoso, declared in her 1999 inaugural address that society has often failed to recognize women's political talents. She asserted that both women and men are equally capable of successfully performing as national politicians and called for society to allow women to take up leadership roles (González 1999). These presidentas' evocation of gender issues in high-profile speeches suggests that they perceived the entry of women into politics as a goal that their constituencies shared, offering a voter-oriented reason to appoint ministras.

Yet bottom-up pressures from voters are not the only possible drivers of executives' cabinet choices. Networks are especially relevant for appointment processes, which often rely on personal trust and recommendations (Amorim Neto 2006; Camerlo and Pérez-Liñán 2015; Martínez-Gallardo 2012). The second reason that presidentas would appoint more ministras than male presidents highlights the consequences of homophily, the tendency of individuals with similar characteristics to "flock together." Recurrent throughout societies, homophily exerts a powerful homogenizing effect on perceptions and worldviews (Marsden 1988; McPherson and SmithLovin 1986). Sociological research on gender homophily, coupled with feminist institutionalist scholarship on gendered networks, suggests that elite female politicians, compared to their male counterparts, tend to interact and exchange information more frequently with other women (Bjarnegård 2013; Crowder-Meyer 2013; Kenny 2013). However, because men continue to dominate most political networks, it is likely that presidentas' networks still contain a male majority. The difference is that presidentas' networks will have a higher percentage of women than male presidents' networks. 
A comparatively higher proportion of women in presidentas' networks could lead to a greater likelihood that a presidenta will name a female instead of a male minister. Scholars of cabinet selection tend to agree that executives look for "loyal" and "like-minded" ministers to faithfully pursue the administration's policy agenda (Huber and Martínez 2008; Dewan and Myatt 2010; Indridason and Kam 2008; Martínez-Gallardo and Schleiter 2015). Regarding loyalty, presidents seek evidence-direct and indirect-that the ministerial candidate will not betray them. Repeated personal interactions, along with references from trusted advisers, create trust, reduce uncertainty, and therefore can enhance mutual perceptions of loyalty.

As for like-mindedness, a presidenta also is more likely than a male president to exchange political information regularly with other elite female politicians. This gendered flow of information may help foster mutual perceptions of like-mindedness on a range of political issues. Because these homophilous interactions foster mutual perceptions of both loyalty and like-mindedness, these characteristics are best conceived as intertwined rather than independent. All of this suggests that while homophily under a male president can work against women with ministerial ambitions, under a female president, homophilous forces can work against men's overrepresentation in cabinets.

\section{Presidentas' Constraints AND THE FEMALE SuPply}

Aside from nationality and age requirements for ministers, Latin American constitutions impose virtually no restrictions on selecting cabinet members. How does a citizen come to be considered for a ministerial position? Latin American presidents draft their lists of ministeriables according to informal norms that define the supply of "qualified" ministerial candidates. This helps explain why, when women constitute half the general population and possess similar education levels to men, the female ministerial pool turns out to be substantially shallower than the male pool (Borelli 2002; Franceschet 2016).

Executives seek "competent" appointees to execute their legislative agendas. Competency - the perceived capacity to achieve presidents' goals-is associated with notions of political capital, technical expertise, and partisan ties (Dewan and Myatt 2010; Huber and Martínez 2008; Martínez-Gallardo and Schleiter 2015). Following this concept, Escobar-Lemmon and Taylor-Robinson (2014) demonstrate that Latin American presidents recruit ministers with "political capital resources" (PCRs), which they operationalize as political skills, ties to organizations related to the cabinet ministry, and status as an expert on the ministry's portfolio. More PCRs do not guarantee that ministers indeed will perform their jobs effectively, but Escobar-Lemmon and Taylor-Robinson do find statistical evidence that ministers with more PCRs tend to be more successful. ${ }^{2}$ All of this suggests that because men continue to dominate politics, they are more likely to possess PCRs, and thus the pool of male ministerial candidates will tend to be deeper than the pool of female candidates. 
In Latin America's presidential systems, the relative importance of each PCR may vary. For example, in multiparty systems, party leadership experience and hence, reputation among party elites is a particularly relevant resource. In countries such as Brazil and Chile, presidents tend to abide by Gamson's Law, distributing ministerial assignments among party members (Carroll and Cox 2007). This allows presidents to preserve coalition discipline and legislate effectively. Party leaders often recommend other political elites as ministerial candidates, and thus a positive reputation among party elites is often the key first to qualifying as a ministerial candidate and then potentially to earning an appointment. ${ }^{3}$

The concept of ministerial supply employed here diverges from conceptions of supply in some women-in-politics scholarship (Hinojosa 2012; Inglehart and Norris 2003). Revised modernization theories often argue that the supply of female politicians is growing, and this literature operationalizes supply with national-level measures of gender equality; for example, female fertility rates and female participation in the labor force. However, in a global study of cabinets, Krook and O'Brien (2012) found that mass indicators of gender equality are relatively poor predictors of female ministerial appointments.

In contrast to that operationalization of supply, this article's concept of supply could be operationalized by a variety of elite-based factors. These include women's national political trajectories, women's experience as leaders in the business and intellectual spheres, and their standing among (historically male) party leaders. Yet however reliable these factors are, quantitative cross-national data on them are unavailable.

This study therefore uses cabinet appointment theories to derive two determinants of the quantity of female ministeriables: timing within a presidential administration and gender stereotypes associated with ministries. Considering timing, Dewan and Myatt $(2010,2012)$ have formalized the argument that the pool of all ministerial candidates is largest at the beginning of executive terms. Executives routinely replace ministers who unexpectedly underperform, become implicated in a scandal, or retire for exogenous reasons. ${ }^{4}$

Because replacements happen relatively quickly and the candidate pool is finite, by the end of their administrations, executives are often forced to substitute some of their once-preferred ministers with their second- and third-choice candidates. They contend that the supply of high-quality ministers eventually can be depleted, thereby diminishing cabinet performance. Dewan and Myatt's influential models $(2010,2012)$ generate the expectation that presidents are best equipped to pursue their preferences at the beginning of their administrations, when the talent pool is deepest and executives can select their most desired candidates.

Being shallower than the male pool, the female ministerial pool is even more prone to depletion. This leads to the first hypothesis about the conditions under which presidentas will name more women. In light of the presidenta mandate and gendered networks, presidentas are more likely to make a difference in terms of women's cabinet representation at the beginning of their administrations than at the end. 
In addition to intra-administration timing, the second factor that affects the supply of female ministerial candidates and thus reduces presidentas' decisionmaking latitude relates to gender stereotypes. Certain ministerial portfolios are often associated with stereotypically feminine characteristics (for example, education and health), while other ministries are associated with stereotypically masculine characteristics (such as finance and agriculture) (Davis 1997; Krook and O’Brien 2012). Multiple studies in Latin America and other parts of the world show that women tend to be disproportionately assigned to "feminine" ministries (Escobar-Lemmon and Taylor-Robinson 2005, 2009).

There are at least two reasons why women are more likely to possess political capital resources related to stereotypically feminine ministries, and therefore why the female ministerial pool would be relatively larger for "feminine" rather than "masculine" or "neutral" ministries. Theories of the gendered division of labor predict that women will possess more ties to organizations relevant to "feminine" ministries and more technical expertise in "feminine" domains. 5 Women could "naturally" gravitate toward these areas, but the male political establishment's sexism also could play a role. For example, Heath et al. (2005) show that in Latin America, male legislators marginalize their female counterparts by assigning them to "feminine" committees, which often are low-prestige ones.

Female politicians may accrue more political capital resources disproportionately related to "feminine" ministries not just because women are necessarily more attracted to these domains, but also because male elites have limited these women's political experiences to "feminine" areas. In either case, "feminine" ministries are more likely to have an abundant pool of female candidates-that is, women with political capital resources—-than "masculine" or "neutral" ministries. Because elite women are more likely to have political capital resources tied to "feminine" ministries, the pool of female ministerial candidates is deepest for these ministries. Presidentas therefore are least constrained in appointing women to "feminine" ministries.

\section{An Illustrative Case: BACHELET'S First-TERM CABINET}

Michelle Bachelet's first-term cabinet selections resulted in Chile's first gender parity cabinet. This case constitutes an extreme instance of a president striving to advance women's presence in the executive branch (Gerring 2007). Extreme cases are useful for conducting plausibility tests and tracing pathways between the primary independent and dependent variables (here, presidents' sex and ministers' sex). This case study illustrates how the theorized mechanisms of popular mandates and gendered networks both seemed to drive the relationship.

On January 15, 2006, the Socialist Bachelet earned over 53 percent of the vote in the second round-handily defeating her conservative male opponent. The media immediately began to pepper her with questions concerning her ministerial lineup, and Bachelet told the press her cabinet would be "made up of the best." What did "the best" really mean? 
Bachelet had three aspirations. First, she asserted that nadie se repite el plato (nobody goes for seconds) (Navia 2007). This phrase indicated that she looked for new faces within the dominant coalition, and the promise seemed to respond to a widespread perception (confirmed by polling data) that Chileans, after 15 years of Concertación rule, were tired of the political establishment and desired new leadership.

The second aspiration — not entirely at odds with the first—was to assemble Chile's first gender parity cabinet. Bachelet had pledged to voters during the presidential campaign that she would allocate half of her cabinet to women. Gender parity challenged traditional norms for the criteria used to evaluate ministerial candidates, and opposition to this promise emerged both within and outside the Concertación (El Mercurio 2006; Solinas 2007).

Bachelet's first and second criteria constituted responses to popular demands for certain kinds of leaders, while her third criterion responded to concerns of political elites. Cuoteo, or party quotas, was not a priority that Bachelet herself trumpeted but was nonetheless evident, given the historical context, party leaders' statements, and journalists' speculations (Siavelis 2006). Even though, constitutionally, presidents can appoint virtually any citizen to their cabinet, Bachelet confronted intense pressure to continue the Concertación tradition of distributing posts among the coalition's party elites. Two days before the second round, coalition parties were preparing résumés and reference letters for their proposed ministerial candidates (Astorga 2006).

Socialist Party senator Carlos Ominami asserted that Bachelet's cabinet should reflect the substantial number of Socialist votes (Alcaíno Padilla 2006). Radical Party president José Antonio Gómez said he expected that members of his party would be named to the cabinet, since, during the election, the radicals managed to elect three senators and seven deputies (UPI Chile 2006a). "If the commitment is not fulfilled, we are going to act with absolute independence," he affirmed. Bachelet's ability to legislate would be jeopardized if she did not—at least partially—satisfy party leaders' appetite for ministerial posts.

Chile's presidenta therefore faced a tall order. She aimed to deliver on her campaign promises and appease her coalition's party leaders. On January 30, 2006, Bachelet unveiled Chile's first gender-parity cabinet. The cabinet also, according to the press, featured new talent and partisan balance. Seven positions were allocated to the Christian Democrats, five to the Party for Democracy, four to the Socialists, three to Independents, and one to the Radical Party (UPI Chile 2006b). Bachelet appeared to meet all of the goals she had proposed on her inauguration; she was relatively less constrained, because supply is most abundant at the beginning of a presidential administration. 


\section{Mechanisms}

Why did Bachelet name so many women? She had promised voters a gender parity cabinet. Yet in addition to this clear mandate, gendered networks appeared to play a role. Franceschet's interviews with Chilean politicians reveal that Bachelet seemed to interact more with elite women (potential ministerial candidates) than did her male predecessors. According to one interviewee, Bachelet nominated more women than other Chilean presidents "because she knew more women and she saw more women. Women see women. Men do not see women” (quoted in Franceschet 2016).

Some news reporters speculated that Bachelet, like many Latin American presidents, would name some of her "friends" to ministerial positions. All of the alleged friends mentioned were women: Estela Ortiz, María Angélica Álvarez, and Ingrid Antonijevic. Ortiz ended up as director of the National Preschool Association (JUNJI). Álvarez became Bachelet's agenda director, and Antonijevic was named economy minister (Economía y Negocios 2006). Bachelet's health minister, María Soledad Barría, was also described as Bachelet's "friend." Like the nominations of other Latin American presidents, Bachelet's appointments-although not all of them were ministerial — suggest the relevance of personal networks, which can foster mutual perceptions of trust, loyalty, and like-mindedness. Nevertheless, because men continued to dominate the Concertación's political establishment, women in Bachelet's expansive political networks did not seem to outnumber men, and Bachelet also named male ministers with whom she had previously worked and therefore trusted.

Both mandate and network mechanisms thus appear as key factors for Bachelet's decisionmaking. First, Bachelet's promise of gender parity during the campaign provides straightforward evidence for the mandate mechanism. Second, evidence from personal interviews and the national press suggests that Bachelet personally knew more female ministerial candidates than her male predecessors did and appointed at least a handful of female friends or acquaintances.

\section{End of Parity}

In accordance with Dewan and Myatt's theory (2010, 2012), the supply of female ministerial candidates seemed to diminish over time. Soon after her presidential "honeymoon," Bachelet confronted several crises that prompted her to fire and hire ministers.

The first crisis that prompted a cabinet shakeup was a series of student protests known as the Penguin Revolution. Hundreds of thousands of students took to the streets to demand education reforms. Bachelet shuffled her cabinet and managed to maintain gender parity - in part because the education minister happened to be male and could be replaced by another male without affecting the proportion of ministras.

The second crisis was the disastrous implementation of Transantiago, the capital's renovated public transportation system. Chileans questioned Bachelet's leadership and decisionmaking capacity, her approval rating fell to about 40 percent, and the presidenta publicly apologized for her administration's mistakes. She was able to 
maintain relative partisan balance after reshuffling her cabinet, but the modifications ended gender parity. Consistent with this article's argument, Bachelet tended to name a high proportion of women to stereotypically "feminine" ministries. Women in her 2006 inaugural cabinet occupied 80 percent of "feminine" ministries, and after Bachelet's first cabinet shuffle, women led 100 percent of such ministries.

The case study thereby advances this article's theoretical argument. Given a perceived popular demand for gender parity and a network with a seemingly higher proportion of women, Bachelet tended to appoint more women when her female pool was largest—at the beginning of her administration and to "feminine" ministries. The next section tests whether the hypotheses hold up cross-nationally and over time.

\section{DATA AND MODELING}

To conduct statistical tests, an original dataset was constructed of ministers appointed by all democratically elected presidents in 18 Latin American countries from 1999 to 2015. The online CIA directory of world leaders lists minister names and ministries by monthly intervals, and this study sampled both inaugural and end-of-term cabinets (CIA 2015). To help preserve balance among the number of observations per president, only the first inaugural term and the end-of-term cabinet for each president who was elected to a consecutive term were included. ${ }^{6}$

The first modeling objective is to find out whether presidentas "make a difference" in terms of female ministerial appointments. "Making a difference" refers to whether presidentas display statistically different nomination patterns from male presidents. Three dependent variables assess this: the percent female in a cabinet (OLS), a count of women in cabinets (Poisson), and the minister's sex (logistic). The unit of analysis for the OLS and Poisson models is the cabinet, and the dataset includes 104 cabinets. The unit of analysis for the logistic models is the minister, coded 0 for male and 1 for female. This dataset includes 1,908 ministers. The same president appoints all of her or his ministers, and therefore observations of ministers appointed by the same president are likely to be correlated in the logistic models. Fifty-four is a large enough number to use either random effects for president or to cluster the standard errors by president (Angrist and Pischke 2008). I report the results for the random effects models, and all results are robust to clustering the standard errors by president.

The first set of models includes all the observations in the dataset to test whether presidentas make an impact on women's cabinet representation overall. The argument of this study also implies that presidentas' impact is most likely to be statistically robust when presidentas are least constrained by the pool of female ministerial candidates. Following Dewan and Myatt's modeling of pool depletion (2010), I first expect presidentas to name more women to "inaugural" cabinets but not necessarily "end-of-term" cabinets. I disaggregated the data by "inaugural" and "end-ofterm" cabinets and ministers to test these predictions. ${ }^{7}$ I again use OLS, Poisson, and logistic models to examine the potential presidenta effect. 
The next empirical implication is that presidentas are most likely to advance women's representation for "feminine" ministries. Only the logistic models can test the ministry gender hypotheses (feminine vs. masculine or neutral), since these data are at the minister level (the dependent variable being the minister's sex). I used Krook and O'Brien's 2012 gender stereotype classification and coded each ministry as -1 if feminine, 0 if neutral, and 1 if masculine. ${ }^{8}$ This generated the variable ministry gender. Many scholars have pointed out that "feminine" classifications often overlap with low-prestige classifications. To untangle the effect of ministry gender from ministry prestige, I coded low-prestige ministries as 1, medium-prestige ministries as 2, and high-prestige ministries as 3, according to Escobar-Lemmon and Taylor-Robinson's 2005 classification of Latin American ministries. The ministry gender and prestige categories indeed tend to correlate $(p=0.53)$. The logistic models-featuring minister-level data-thereby employ ministry prestige and ministry gender variables.

The OLS and Poisson models are not equipped to test the ministry gender hypotheses because they contain cabinet-level rather than minister-level data. Yet these models also must control for prestige and gender because these variables could confound the relationship between presidentas and ministras. Cabinets vary crossnationally and temporally in terms of the proportion of high-, medium-, and lowprestige ministries and the proportion of feminine, masculine, and neutral ministries. These models require modified versions of the variables, since presidents with a higher proportion of high-prestige or "masculine" ministries may face greater constraints in naming women to their cabinets. I totaled the ministry prestige and ministry gender scores and averaged them for each cabinet to produce the variables $c a b$ inet prestige score and cabinet gender score. Higher-prestige scores mean that the cabinets contain a greater proportion of prestigious cabinet positions. Higher gender scores mean the cabinets are more "masculine."

All models control for additional variables that could mediate or confound the relationship between presidentas and ministras. First, female presidents could be elected in times and places characterized by greater female access to elite positions. I use two proxies to account for this possibility: the percent female in Congress and the number of women in the predecessor's end-of-term cabinet. ${ }^{9}$ The percentage of women in Congress routinely appears in models of female appointments (Arriola and Johnson 2014; Claveria 2014; Escobar-Lemmon and Taylor-Robinson 2005; Krook and O'Brien 2012; O'Brien et al. 2015). Data on the percent female in the legislature come from the Inter-Parliamentary Union (IPU 2015). If a country has both an upper and a lower chamber, I average the percentages of each chamber. I include the second proxy because some of the presidentas in the sample were ministers in their predecessors' cabinets and identified with the same party. Presidentas potentially could govern countries that already are on a path toward greater female presence in cabinets.

I also control for presidential ideology, since presidentas may appoint more women not because of their same sex but because of their common ideology. In Latin America, ideology generally is conceptualized on a left-right continuum 
according to state intervention policy stances (Kitschelt et al. 2010). Some scholarship suggests that left-leaning presidents express a commitment to social equality and that therefore they are more likely to appoint women (Levitsky and Roberts 2011). However, regional public opinion polls show that female citizens in Latin America often self-identify as more conservative, and therefore conservative presidents could strive to please women by naming more ministras (AmericasBarometer 2004-12). Since the relationship between ideology and female appointments thus may be nonlinear, I include dummies rather than a single ordinal variable. I coded president's ideology according to Murillo et al. 2010. Three presidentas were classified as left (Bachelet, Fernández, and Rousseff) while one was classified as far right (Moscoso) and another as center (Chinchilla).

Furthermore, time may confound the relationship between presidentas and ministras. Presidentas tend to appear in the sample at later time periods, and the number of ministras increases over time as well. For the logit models, I control for the year the minister was appointed, and for the OLS and Poisson models, I control for the year the cabinet was appointed. I also include a cabinet size variable (Escobar-Lemmon and Taylor-Robinson 2005).

\section{RESULTS}

Table 1 shows the results for the full OLS, Poisson, and logistic models, which examine both inaugural and end-of-term cabinets and all ministry gender types. The presidenta coefficient is positive and significant at the $\mathrm{p}<0.10$ level in all the models. This is consistent with the argument that, ceteris paribus, presidentas tend to enhance women's cabinet representation. The OLS results show that the presence of a presidenta increases the percent female in a cabinet by just 6 percent.

I used the margins Stata command to calculate the predicted probabilities for the number of female ministers (Poisson models) and the probability of observing a ministra (logistic models). According to the Poisson results, the presence of a male president generates the prediction of 3 female ministers, while the presence of a presidenta predicts 6 . According to the logistic results, the probability of observing a ministra under male and female presidents is 19 percent and 27 percent, respectively. In other words, the presence of a presidenta augments the probability of observing a female minister by 8 percentage points, or about 40 percent.

A review of the cabinet characteristics for the OLS and Poisson models shows results generally consistent with the anticipated relationships. The cabinet gender score shows the expected sign (negative), and the coefficient is significant. This means that cabinets with a greater proportion of masculine or neutral ministries have a lower percentage female (OLS) and feature fewer female appointees (Poisson). Ministry gender is negative and significant for the logistic model. Cabinet prestige score is not significant for the OLS or Poisson models, but ministry prestige is significant and negative for the logistic model. The percent female in Congress is positive and significant in all of the models, as is the number of women in the predecessor's cabinet. 


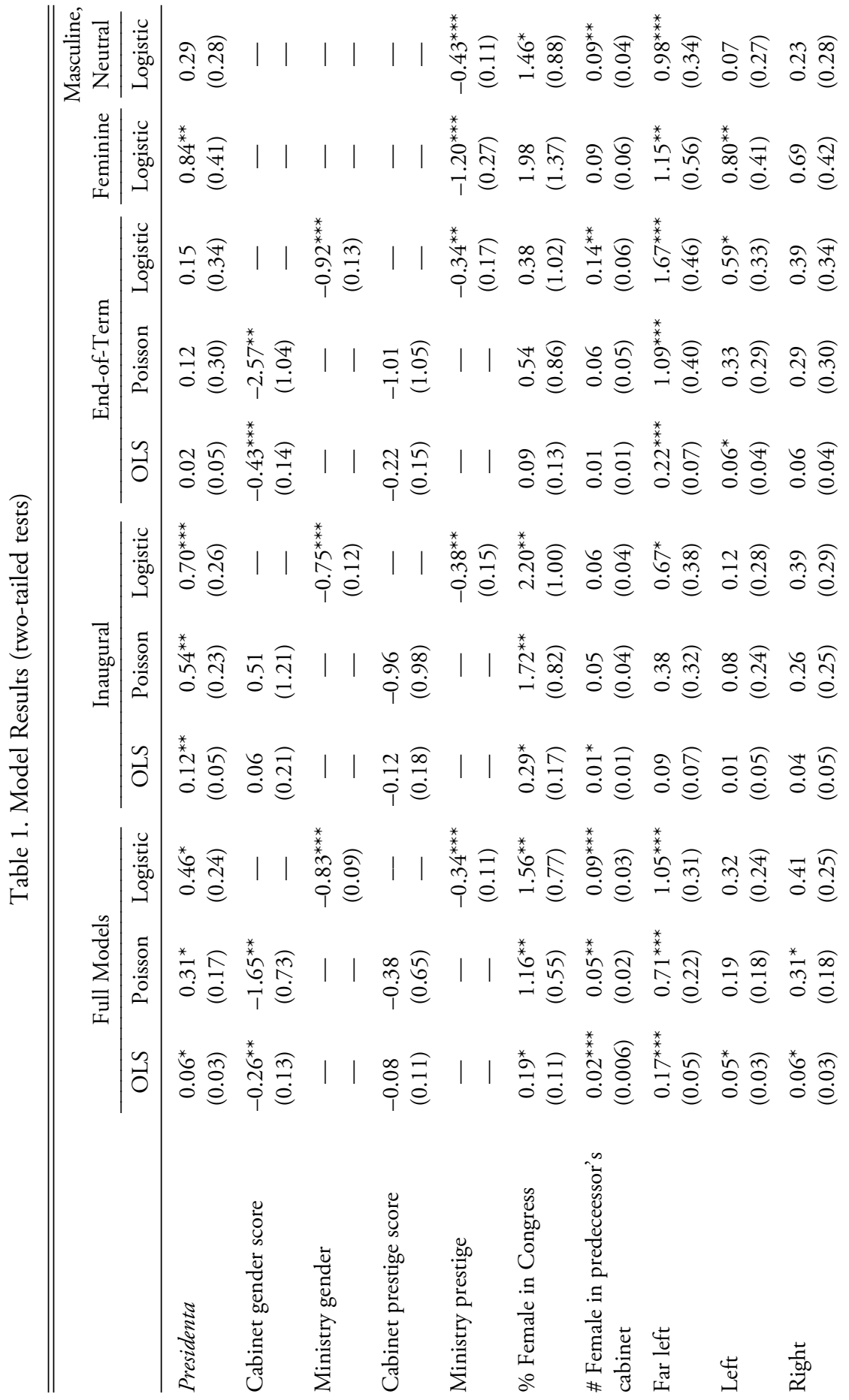




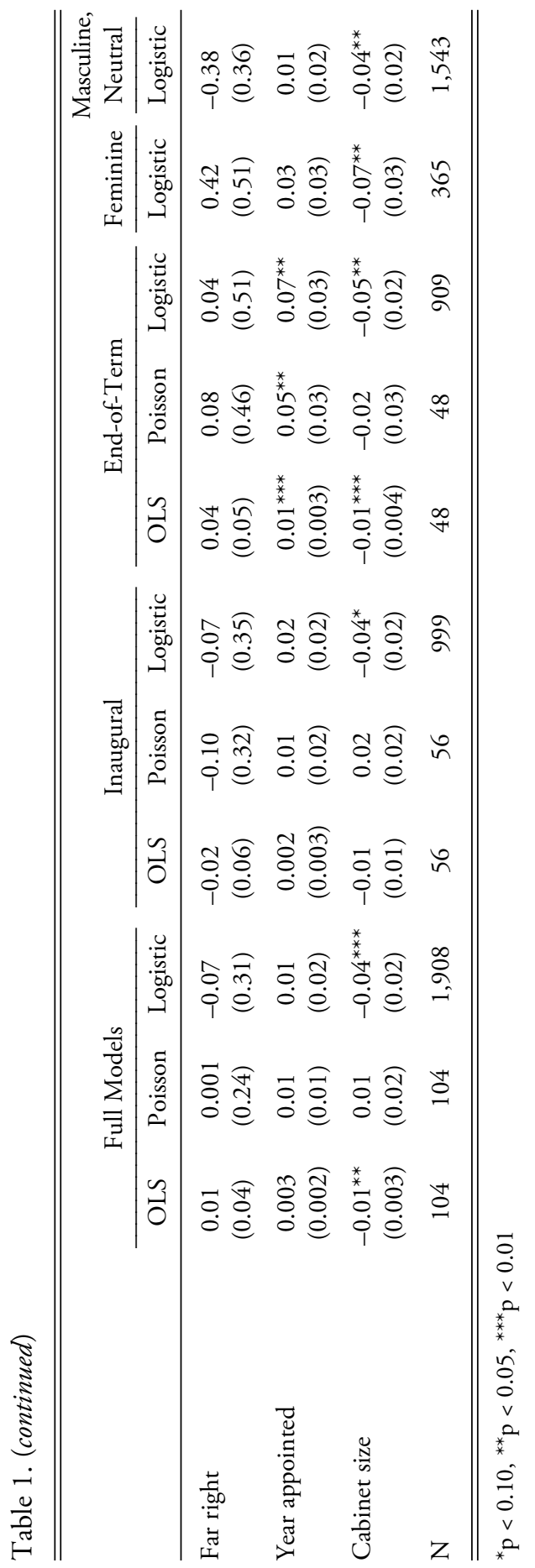


In terms of presidential ideology, far left presidents (none of whom are women) exert a significant and positive impact on women's representation in cabinets. The dummy variable for far left presidents has a larger magnitude than the presidenta variable and is significant at the $\mathrm{p}<0.01$ level. This result on the impact of left-leaning male leaders confirms findings from O'Brien et al.'s 2015 study, which shows that left-leaning prime ministers tend to nominate more women.

Despite these initial results, which reveal that presidentas make a difference when we take into account all the observations, the presidenta coefficient fails to attain the $\mathrm{p}<0.10$ significance level for a few of the robustness checks. Nevertheless, we do find some evidence consistent with the argument that presidentas influence women's cabinet representation overall. Is the evidence stronger when presidentas are least constrained by the supply of female ministerial candidates? Because the pool of female ministerial candidates is deepest at the beginning of the executive's term, presidentas should be most effective in enhancing women's cabinet presence right after presidential elections. The ministerial supply diminishes as presidents replace ministers over the course of their administration, and presidentas are less likely to have an impact when they are about to hand power off to their successor.

The middle columns in table 1 show the first set of results, consistent with this argument, concerning the conditions in which presidentas are most likely to make a difference. The presidenta coefficient is positive and significant at the $\mathrm{p}<0.05$ level for all the inaugural models and fails to reach significance for all the end-of-term models. I again used the margins command to generate predicted probabilities for the other inaugural models. The Poisson results show that the number of ministras under male presidents is 4 , and under presidentas, that number jumps to 8 . The logistic results further reveal that the probability of appointing a ministra is 0.21 for male presidents, while this probability is 0.32 for female presidents, a difference of 43 percent. $^{10}$

The results again show that far left presidents exert a significant and positive impact on women's representation, according to the results for the inaugural logistic model and all the end-of-term models. This might suggest that unlike presidentas, far left presidents may not be so prone to a depleted pool of female ministerial cabinets. This could be because parties from the far left are more likely to have a plentiful supply of female politicians - and hence women with political capital resources (Beckwith 2000). Presidents with other ideologies_-such as the presidentas in this study — may be more susceptible to female pool depletion.

The rest of the inaugural and end-of-term results are roughly similar to those produced by the full model. Cabinet gender is significant and negative for the endof-term cabinets but not for the inaugural cabinets. Furthermore, ministry gender and ministry prestige are significant and negative for the logistic models. The percent female in the legislature is significant and positive for the inaugural models, and the number of women in the predecessor's cabinet is significant for the OLS inaugural model and the logistic models.

I also argue that presidentas are most likely to improve women's presence for "feminine" ministries because they face weaker constraints than for "masculine" and 
"neutral" ministries. Table 1's final columns display results consistent with this article's hypotheses: the presidenta coefficient is positive and significant at the $\mathrm{p}<0.05$ level for the feminine model but not for the masculine/neutral model. The probability of a male president's appointing a ministra to a feminine ministry is 0.31 , and the probability of a female president's nominating a woman to the same kind of ministry is 0.46 , about a 48 percent increase.

As expected, ministry prestige is negative and significant at the $\mathrm{p}<0.01$ level. The percent female in Congress and the number of women in the predecessor's cabinet are not significant for the feminine model, but both are significant and positive for the masculine/neutral model. Again, far left presidents name more women to both "feminine" and "masculine" or "neutral" posts, perhaps suggesting that these leaders are less constrained by gender-specific ministerial pools.

As a robustness check, I used data from the ILO and the World Bank to include three indicators of female empowerment that vary by country and year (see table 1 in the online appendix). Female in labor force is the percent of women 15 years and older who are actively employed. The second indicator is fertility rate, the number of children born to women. The third is female education, the female to male ratio of tertiary enrollment. Adding these female empowerment variables does little to change the results. The presidenta coefficient is always as significant at the same level as the models without the controls for female empowerment, with one exception: for the Poisson model, the presidenta coefficient is positive, but nevertheless fails to reach conventional significance levels $(\mathrm{p}=0.13)$. I also removed Bachelet's 2006 inaugural cabinet from the models to see whether the results were robust after excluding this extreme case. The presidenta coefficient failed to reach significance for the full models, but again reached significance for almost all the inaugural and feminine models (see table 2 in the online appendix). As a third robustness check, I ran all the logistic models with standard errors clustered by president instead of random effects. All the main results remain unchanged (see table 3 in the online appendix).

In sum, the model results provide some evidence that presidentas make a difference when we observe both the inaugural and end-of-term cabinets and all ministry types. Consistent with this article's argument, we find the stronger evidence that presidentas make an impact under two conditions: at the beginning of their administrations and in "feminine" ministries. I have argued that both of these conditions are best interpreted as indicators of a relatively abundant supply of female ministerial candidates. We can also consider a few rival interpretations.

\section{Alternative Explanations}

Could a lack of political capital instead of a lack of supply act as presidentas' primary constraint on female ministerial appointments? Presidents' political capital is often operationalized as public approval, the margin of victory in the previous election, and partisan support in Congress (Light 1999). According to this alternative explanation, presidentas face a tradeoff between like-mindedness, or loyalty, and "competence." Presidentas have strategic reasons to name women, but because of this trade- 
off, doing so requires extra presidential capital. Presidentas therefore improve women's representation in executive cabinets only at the beginning of their terms, when they are still on their "honeymoon" and tend to enjoy greater public approval.

It is likely that both measures of presidential capital and female ministerial supply can be interpreted as constraints on presidentas appointments, and because presidents often shuffle their cabinets when their popularity falls, both of these variables tend to decline over time (Light 1999). Diminished capital and supply could together contribute to the empirical finding on inaugural cabinets.

While we cannot completely untangle the presidential capital versus supply variables with the Bachelet case, a quick look at her cabinet decisionmaking yields little immediate evidence for this rival explanation. Women's cabinet presence under Bachelet did not seem to covary well with her political capital. For one thing, Bachelet's coalition controlled a similar percentage of the lower and upper chambers-that is, majorities ranging from 54 to 56 percent—during her 2006 and 2014 terms. Thus, the party support in Congress component varies little and cannot help explain variations in women's cabinet presence. Second, Bachelet won a greater vote share in 2013 (about 62 percent) compared to 2006 (about 53 percent). Yet she named women to 50 percent of her cabinet in 2006 and just 39 percent in 2014. Third, Bachelet ended her first term with record-breaking popularity—about 80 percent approval—but she never reobtained a gender parity cabinet.

Moreover, if the presidential capital argument were true, we would expect the costs of naming ministras to depend on ministry prestige. According to this alternative explanation, presidentas should be most willing to sacrifice "competence" for low-prestige ministries, since the costs would be lower than the costs of appointing women to high-prestige ministries. ${ }^{11}$ The empirical implications of the presidential capital argument are that presidentas make a difference for low-prestige and possibly medium-prestige but not high-prestige posts. Empirically, however, the presidenta variable is positive and significant at the $\mathrm{p}<0.10$ level when we observe either lowor high-prestige ministries, but not medium-prestige ministries. ${ }^{12}$

In sum, although presidential capital usually does offer presidents greater decisionmaking latitude and thereby makes the argument appear theoretically compelling, this study reveals little empirical evidence consistent with its observable implications. Future research nevertheless should attempt to puzzle out the ministerial pool and political capital variables by process tracing cabinet nominations of other presidentas and expanding the cross-national, time-series dataset to include direct measures of political capital.

A rival interpretation of the ministry gender results relates to the role of public opinion in determining cabinet appointments. This article argues that presidentas tend to name more women to "feminine" ministries because the supply of candidates is deepest for these ministry types. However, it could be that voters prefer to see ministras in charge of "feminine" ministries and presidentas appoint more women at the beginning of their terms because this is when the public pays the most attention (Martin 1988). Presidentas' decisionmaking is motivated exclusively by public demand, according to this account. 
One way to probe this explanation is to see whether presidents seeking immediate re-election reshuffle their cabinets ostensibly to earn greater public support. Using the CIA world leaders information, I reviewed ministerial lists for the months leading up to the election contests for all presidents seeking re-election. Ministerial lineups were extremely stable, as cabinet shuffles rarely appeared during these relatively short campaign periods. There were no signs that these executives began to appoint more women to feminine ministries—or to any cabinet positions-in anticipation of the next presidential election.

Thus, a pure public demand theory falls short of accounting for this article's main empirical results. This article's elite-based supply explanation therefore seems to constitute a more plausible interpretation of the empirical results concerning ministry gender type and administration timing.

A third alternative explanation again relates to the finding that presidentas are more likely to appoint women to "feminine" ministries. Instead of supply factors accounting for these results, they may be driven by the fact that presidentas and ministras are like-minded on precisely the issues handled by "feminine" ministries, such as health, corruption, and social welfare. It is possible that presidentas and ministras may share similar views, especially on issues handled by "feminine" ministries. Research on homophily and gendered networks would nevertheless predict that elite female politicians would share information and exchange ideas on a broader range of topics. Furthermore, given that loyalty and like-mindedness are related characteristics, it is unclear why presidentas would value these traits only for "feminine" positions and not others as well. Again, future research should explore homophilous interactions among elite politicians to sort out exactly when homophily plays a role in generating perceptions of like-mindedness.

\section{Conclusions: Mandates, Networks, AND INFORMAL CONSTRAINTS}

Men won every Latin American presidential election from colonial independence until the 1990s. Scholars still know very little about presidentas' consequences. Some work has examined individual presidentas (Jalalzai and dos Santos 2015; Staab and Waylen 2016), but this study constitutes the first cross-national analysis of the impact of Latin America's female presidents.

More specifically, the present article contributes to this literature by generating a priori explanations for why presidentas would deploy their appointment powers to improve women's representation in the executive branch and by theorizing about some of the informal constraints preventing presidentas from doing so to a greater extent. The proposed theory yielded specific implications concerning the conditions in which presidentas are most likely to make a difference, and these predictions hold up according to the empirical tests.

This study highlights the power of unwritten norms for presidential decisionmaking and therefore contributes to the growing research on informal norms in Latin America and how institutions might be gendered (Annesley 2015; Helmke 
and Levitsky 2006; Krook and Mackay 2010). Michelle Bachelet may have insisted in 2005 that her ministerial decisions "depend on me. I am the one who decides who will be my ministers" (UPI Chile 2005). Latin American presidents do face minimal formal restrictions on their appointment powers. Yet this article makes clear that informal constraints can powerfully dictate executive nominations.

How, then, should we characterize presidentas' impact on women's cabinet presence? Male presidents have slowly been nominating more women to their cabinets since the return to democracy in the 1980s, and presidentas impact thus is best conceptualized as one of acceleration rather than initiation. Provided that elite women continue to accrue more political capital resources, this argument cautiously predicts that future presidentas will advance women's representation more than this first generation of presidentas already has. As supply constraints ease, subsequent presidentas will pursue their strategic preference for ministras to a greater extent than this first generation of presidentas has. In this sense, this study could be interpreted as a study of "contagion" when the enhanced presence of women in one political office leads to greater gains for women in other offices (Thames and Williams 2013).

Yet this optimistic forecast requires a caveat. One of the mechanisms driving the positive relationship between presidents' sex and women's cabinet presence is a public mandate. The fact that women have already shattered this glass ceiling in several countries could mean that subsequent presidentas may hesitate to interpret their mandates as popular calls for enhanced female leadership. This means that as presidentas' novelty erodes, their accelerating effect on women's representation in the executive branch could slow down. Although no country has elected two different presidentas, the Bachelet case offers some evidence of that presidentas' impact could diminish over time. Bachelet in 2013 ran as a former president—not as Chile's first female president, as she did in 2005. Although she did say in the run-up to the elections that she would like to assemble a gender parity cabinet, this was not a central component of her 2013 campaign. Overall, major campaign promises—such as education and health care reforms-were far more prominent components of her agenda than gender equality. In light of this, it is less surprising that women comprised 39 percent of her 2014 inaugural cabinet—far higher than the regional average of 20 percent but below parity.

Finally, female chief executives' impact may depend on whether a country features a presidential or a parliamentary system. Latin American presidents can nominate virtually any citizen, but in many parliamentary systems, prime ministers must choose their cabinets from a smaller pool of members of Parliament. It is unsurprising, then, that the results of this study contradict O'Brien et al.'s 2015 findings on the impact of female prime ministers in advanced industrial democracies. Evidence that female prime ministers do not appoint more women to their cabinet than male prime ministers could be at least partly explained by a more restricted pool of female ministerial candidates. Nevertheless, as more women are elected to legislatures globally, the supply of female ministerial candidates may become less of a constraint for female chief executives around the world. 


\section{NoTES}

I thank Leslie Schwindt-Bayer, Kenneth Roberts, and four anonymous reviewers for their guidance and suggestions. Participants in the 2013 American Political Science Association meeting, the Rice University American/Comparative Workshop, and Universidad Católica's Seminarios ICP in Chile also provided helpful comments. For tables of all of the results for the robustness checks, see the online appendix at www.reyes-householder.com.

1. Democratically elected presidentas have governed in Costa Rica, Panama, Nicaragua, Chile, Brazil, and Argentina.

2. For the purposes of this article, the supply of ministerial candidates is primarily determined by those who possess PCRs, although other scholars of parliamentary systems continue to debate formal and informal determinants of supply (Annesley 2015).

3. Partisan quotas in coalition governments could diminish the female ministerial supply if allied parties tend to have fewer women with PCRs than the president's party. But if the reverse is true, then partisan criteria could actually provide presidents more options in naming women.

4. Escobar-Lemmon and Taylor-Robinson (2009) found that ministerial careers in Latin America last, on average, about 2.2 years.

5. Gender stereotypes may serve both as a gateway toward a greater female presence and as a hindrance to cabinet gender equality. Nevertheless, this particular issue is beyond this article's scope.

6. End-of-term cabinets are taken from the month immediately before the departing president hands power to her or his successor. All 54 elected presidents have an inaugural cabinet, but not every president has an end-of-term cabinet. The dataset includes only the endof-term cabinets of presidents who already have handed off power or who will do so within a year. Six presidents do not meet this requirement, and therefore their end-of-term cabinets do not appear in the dataset. Aside from those presidents, Alberto Fujimori fled to Japan four months after his second re-election, and only his 2000 inaugural cabinet is included in the analysis. Gonzalo Sánchez de Lozada, Manuel Zelaya, Lucio Gutiérrez, and Fernando de la Rúa were elected and in power for more than a year but did not finish their terms. Their last cabinet configuration was used as their end-of-term observation. Two presidents were reelected nonconsecutively but are still in power, and therefore those presidents have three cabinets (two inaugural and one end-of-term) included. The dataset thus features 104 cabinets total. I later ran robustness checks that dropped Sánchez de Lozada's, Zelaya’s, Gutiérrez's, and de la Rúa's end-of-term cabinets and found that no results changed. See table 4 in the online appendix.

7. End-of-term cabinets might be unusual in ways that could affect the findings. For example, in some countries, ministers with presidential ambitions must resign from their post to run for president. Nevertheless, a large literature argues that ministerial supply depletes over time and models this in similar ways. Although perhaps not ideal, this article's strategy thus appears as the comparatively best way to model supply depletion.

8. All results are robust to recoding the chief of staff and presidency posts as masculine rather than neutral.

9. Both of these variables could also be measures of the supply of elite female politicians - and potentially, female ministerial candidates. My argument suggests that presidentas in times and places with more women in the legislature or more women with ministerial experience are more likely to have an impact on women's cabinet representation. However, the small number of presidentas in this study does not permit enough statistical power to test 
interactions between presidentas and these variables and thereby probe these other empirical implications of my argument.

10. I standardized the variables to compare the OLS coefficients. For the full OLS model, the presidenta coefficient is 0.17 and is significant at the $\mathrm{p}<0.10$ level; for the inaugural OLS model, it is 0.32 and significant at the $\mathrm{p}<0.05$ level; and for the end-of-term OLS model, it is 0.06 and not significant.

11. I thank an anonymous reviewer for this point.

12. Results from these models are available in table 5 of the online appendix.

\section{REFERENCES}

Alcaíno Padilla, Rodrigo. 2006. La propuesta de ominami. El Mercurio (Santiago), January 21. http://diario.elmercurio.com. Accessed February 5, 2015.

AmericasBarometer. 2004-2012. Latin American Public Opinion Project (LAPOP). www. LapopSurveys.org.

Amorim Neto, Octavio. 2006. The Presidential Calculus: Executive Policy Making and Cabinet Formation in the Americas. Comparative Political Studies 39, 4: 415-40.

Angrist, Joshua David, and Jorn-Steffen Pischke. 2008. Mostly Harmless Econometrics. Princeton: Princeton University Press.

Annesley, Claire. 2015. Rules of Ministerial Recruitment. Politics \& Gender 11, 4: 618-42.

Archivo Chile. 2006. Discurso Presidenta Michelle Bachelet. March 11. www.archivochile. com. Accessed February 5, 2015.

Arriola, Leonardo R., and Martha C. Johnson. 2014. Ethnic Politics and Women's Empowerment in Africa: Ministerial Appointments to Executive Cabinets. American Journal of Political Science 58, 2: 495-510.

Astorga, Luz María. 2006. Se asoma el nuevo gabinete. El Mercurio, January 13. www.emol.cl. Accessed February 5, 2015.

Barnes, Tiffany D., and Diana Z. O’Brien. 2015. Defending the Realm: The Appointment of Female Defense Ministers Worldwide. Paper presented at the 4th European Conference on Politics and Gender, Uppsala, June 11-13.

Beckwith, Karen. 2000. Beyond Compare? Women's Movements in Comparative Perspective. European Journal of Political Research 37, 4: 431-68.

Bjarnegård, Elin. 2013. Gender, Informal Institutions and Political Recruitment: Explaining Male Dominance in Parliamentary Representation. New York: Palgrave Macmillan.

Borelli, MaryAnne. 2002. The President's Cabinet: Gender, Power, and Representation. Boulder: Lynne Rienner.

Camerlo, Marcelo, and Aníbal Pérez-Liñán. 2015. Minister Turnover, Critical Events, and the Electoral Calendar in Presidential Democracies. Journal of Politics 77, 3: 608-19.

Carroll, Royce, and Gary W. Cox. 2007. The Logic of Gamson's Law: Pre-election Coalitions and Portfolio Allocations. American Journal of Political Science 51, 2: 300 313.

Central Intelligence Agency (CIA). 2015. Chiefs of State and Cabinet Members of Foreign Governments. https://www.cia.gov/library/publications/resources/world-leaders-1/. Accessed February 5, 2015.

Claveria, Silvia. 2014. Still a "Male Business"? Explaining Women's Presence in Executive Office. West European Politics 37, 5: 1156-76.

Crowder-Meyer, Melody. 2013. Gendered Recruitment Without Trying: How Local Party Recruiters Affect Women's Representation. Politics \& Gender 9, 4: 390-413. 
Davis, Rebecca Howard. 1997. Women and Power in Parliamentary Democracies: Cabinet Appointments in Western Europe, 1968-1992. Lincoln: University of Nebraska Press.

Dewan, Torun and David P. Myatt. 2010. The Declining Talent Pool of Government. American Journal of Political Science 54, 2: 267-86.

2012. Dynamic Government Performance: Honeymoons and Crises of Confidence. American Political Science Review 106, 1: 123-45.

Dollar, David, Raymond Fisman, and Roberta Gatti. 2001. Are Women Really the "Fairer" Sex? Corruption and Women in Government. Journal of Economic Behavior and Organization 46, 4: 423-29.

Dovi, Suzanne. 2002. Preferable Descriptive Representatives: Or Will Just Any Woman, Black or Latino Do? American Political Science Review 96: 745-54.

Economia y Negocios. 2006. Gabinete: Lo que tienen las carpetas. February 6. www.economiaynegocios.cl. Accessed February 5, 2015.

Escobar-Lemmon, María, and Michelle Taylor-Robinson. 2005. Women Ministers in Latin American Government: When, Where, and Why? American Journal of Political Science 49, 4: 829-44.

- 2009. Getting to the Top: Career Paths of Women in Latin American Cabinets. Political Research Quarterly 62, 4: 685-99.

—. 2014. Minorities Not Tokens: Toward Gender Equality Within Cabinets. Paper presented at the American Political Science Association Conference, Chicago, August 28-31.

Fernández de Kirchner, Cristina. 2007. Asunción de Cristina Kirchner. December 10. www.cfkargentina.com. Accessed February 5, 2015.

Franceschet, Susan. 2016. Disrupting Informal Institutions? Cabinet Formation in Chile in 2006 and 2014. In Staab and Waylen 2016. 67-94.

Gerring, John. 2007. Case Study Research Principles and Practices. Cambridge: Cambridge University Press.

González, David. 1999. In Panama’s New Dawn, Woman Takes Over. New York Times, September 2. www.nytimes.com. Accessed February 5, 2015.

Heath, Roseanna Michelle, Leslie A. Schwindt-Bayer, and Michelle M. Taylor-Robinson. 2005. Women on the Sidelines: Women's Representation on Committees in Latin American Legislatures. American Journal of Political Science 49, 2: 420-36.

Helmke, Gretchen, and Steven Levitsky. 2006. Informal Institutions and Democracy: Lessons from Latin America. Baltimore: Johns Hopkins University Press.

Hinojosa, Magda. 2012. Selecting Women, Electing Women: Political Representation and Candidate Selection in Latin America. Philadelphia: Temple University Press.

Huber, John, and Cecilia Martínez. 2008. Replacing Cabinet Ministers: Patterns of Ministerial Stability in Parliamentary Democracies. American Political Science Review 102, 2: 169-80.

Indridason, Indridi H., and Christopher Kam. 2008. Cabinet Reshuffles and Ministerial Drift. British Journal of Political Science 38, 4: 621-56.

Inglehart, Ronald, and Pippa Norris. 2003. Rising Tide: Gender Equality and Cultural Change Around the World. Cambridge: Cambridge University Press.

Inter-Parliamentary Union. 2016. Women in Parliaments: World and Regional Averages. Database. www.ipu.org/wmn-e/world.htm.

Jalalzai, Farida. 2016. Women Presidents of Latin America: Beyond Family Ties? New York: Routledge.

Jalalzai, Farida, and Pedro G. dos Santos. 2015. The Dilma Effect? Women's Representation Under Dilma Rousseff s Presidency. Politics \& Gender 11, 1: 117-45. 
Kenny, Meryl. 2013. Gender and Political Recruitment: Theorizing Institutional Change. New York: Palgrave Macmillan.

Kitschelt, Herbert, Kirk Hawkins, Juan Pablo Luna, Guillermo Rosas, and Elizabeth J. Zechmeister. 2010. Latin American Party Systems. Cambridge: Cambridge University Press.

Krook, Mona L., and Diana Z. O’Brien. 2012. All the President's Men? The Appointment of Female Cabinet Ministers Worldwide. Journal of Politics 74, 3: 840-55.

Krook, Mona Lena, and Fiona Mackay, eds. 2010. Gender, Politics and Institutions: Towards a Feminist Institutionalism. 2010 ed. Basingstoke: Palgrave Macmillan.

Levitsky, Steven, and Kenneth M. Roberts. 2011. The Resurgence of the Latin American Left. Baltimore: Johns Hopkins University Press.

Light, Paul. 1999. The President's Agenda: Domestic Policy Choice from Kennedy to Clinton. Baltimore: Johns Hopkins University Press.

Mansbridge, Jane. 1999. Should Blacks Represent Blacks and Women Represent Women? A Contingent "Yes." Journal of Politics 61, 3: 627-57.

Marsden, Peter. 1988. Homogeneity in Confiding Relations. Social Networks 10, 1: 57-76.

Martin, Janet M. 1988. Frameworks for Cabinet Studies. Presidential Studies Quarterly 18, 4: 793-814.

Martínez-Gallardo, Cecilia. 2012. Out of the Cabinet: What Drives Defections from the Government in Presidential Systems? Comparative Political Studies 45, 1: 62-90.

Martínez-Gallardo, Cecilia, and Petra Schleiter. 2015. Choosing Whom to Trust: Agency Risks and Cabinet Partisanship in Presidential Democracies. Comparative Political Studies 48, 2: 231-64.

McPherson, Joseph Miller, and Lynn Smith-Lovin. 1986. Sex Segregation in Voluntary Associations. American Sociological Review 51, 1: 61-79.

El Mercurio (Santiago). 2006. Diputado Burgos: No estoy de acuerdo con paridad en el gabinete. January 26. www.emol.com. Accessed February 5, 2015.

Murillo, María Victoria, Virginia Oliveros, and Milan Vaishnav. 2010. Electoral Revolution or Democratic Alternation? Latin American Research Review 45, 3: 87-114.

La Nación (San José, Costa Rica). 2010. Discurso de toma de posesión de Laura Chinchilla. May 8. www.nacion.com. Accessed February 5, 2015.

Navia, Patricio. 2007. El tercero es el vencido. Anuario La Tercera. https://files.nyu.edu. Accessed February 5, 2015.

O’Brien, Diana Z., Matthew Mendez, Jordan Carr Peterson, and Jihyun Shin. 2015. Letting Down the Ladder or Shutting the Door: Female Prime Ministers, Party Leaders, and Cabinet Members. Politics \& Gender 11, 4 (December): 689-717.

Palácio do Planalto. Presidencia da República. 2011. Discurso da Presidenta da República, Dilma Rousseff, durante compromisso constitucional perante o congresso nacional. January 1. www2.planalto.gov.br. Accessed February 5, 2015.

Payne, Mark J. 2007. Democracies in Development. Washington, DC: Inter-American Development Bank/International Institute for Democracy and Electoral Assistance.

Phillips, Anne. 1995. The Politics of Presence. Oxford: Oxford University Press.

Reynolds, Andrew. 1999. Women in the Legislatures and Executives of the World: Knocking at the Highest Glass Ceiling. World Politics 51, 4: 547-72.

Schwindt-Bayer, Leslie A. 2010. Political Power and Women's Representation in Latin America. Oxford: Oxford University Press.

Schwindt-Bayer, Leslie A., and William Mishler. 2005. An Integrated Model of Women's Representation. Journal of Politics 67, 2: 407-28. 
Shugart, Matthew Soberg, and John M. Carey. 1992. Presidents and Assemblies: Constitutional Design and Electoral Dynamics. Cambridge: Cambridge University Press.

Siavelis, Peter. 2006. Accommodating Informal Institutions and Democracy in Chile. In Helmke and Levitsky 2006. 33-55.

Solinas, María Teresa. 2007. RN Emplaza al gobierno a terminar con el criterio de paridad y con el cuoteo político. El Mercurio, March 24. www.emol.com. Accessed February 5, 2015.

Staab, Silke, and Georgina Waylen, eds. 2016. Gender, Institutions and Change in Bachelet's Chile. New York: Palgrave Macmillan.

Swamy, Anand, Stephen Knack, Young Lee, and Omar Azfar. 2001. Gender and Corruption. Journal of Development Economics 64, 1: 25-55.

Thames, Frank, and Margaret Williams. 2013. Contagious Representation: Women's Political Representation in Democracies Around the World. New York: New York University Press.

UPI Chile. 2005. Bachelet reitera que habrá paridad de género entre colaboradores de su eventual gobierno. September 29. Retrieved from LexisNexus Academic database. Accessed February 5, 2015.

- 2006a. Bachelet se reunió con los presidentes de la concertación para diseñar futuro gobierno. January 20. Retrieved from LexisNexus Academic database. Accessed February $5,2015$.

2006b. Presidenta electa Bachelet cumplió con nombrar gabinete paritario. January 30. Retrieved from LexisNexus Academic database. Accessed February 5, 2015.

Wangnerud, Lena. 2009. Women in Parliaments: Descriptive and Substantive Representation. Annual Review of Political Science 12: 51-69.

\section{SUPPORTING INFORMATION}

Additional supporting materials maybe found with the online version of this article at the publisher's website:

1. Online Appendix

2. PresRise Cabinet-level data

3. PresRise Minister-level data

4. PresRise Models Do File 